\title{
Product Development of Fried Shallot from Dairi Potentiates as Souvenir
}

\author{
Hadassah Elisabeth $^{1}$, Tabligh Permana ${ }^{1 *}$, Elisabeth K. Prabawati ${ }^{1}$ \\ ${ }^{1}$ Food Technology, Faculty of Life Sciences and Technology, Swiss German University, Tangerang, 15143, \\ Indonesia \\ "Corresponding author.Email: tabligh.permana@sgu.ac.id
}

\begin{abstract}
Dairi regency is rich with their horticultural plants, especially shallots. But shallots are seasonal plants which affect the price fluctuation even though it has a big potential. The importance of this research is developing a product from Dairi shallot in order to stabilize the market price of shallot, increase the shelf life, and add more economic value. In addition, it is expected to support the Toba Lake tourism and increase the welfare of people in Dairi regency. The objectives are evaluating the sulphur and moisture content of Dairi shallot, determine the most preferred type of fried shallot based on sensory evaluation, determine the most appropriate packaging based on stability assessments, evaluation of market acceptance of the developed product as souvenir of Toba Lake tourism, and assess the safety parameter and nutritional value according to BPOM regulation. The results showed that Dairi shallot has different moisture content $(81.64 \%)$ and sulphur content $(612.215 \mathrm{mg} / \mathrm{kg})$ from Brebes and Sumenep shallot. And the best product was fried shallot that was soaked in salt solution. Both packaging was appropriate but plastic jar was the chosen one. Almost all respondents would like to buy the developed product. The quality of product developed and nutritional value met the BPOM safety regulation.
\end{abstract}

Keywords: shallot, fried shallot, Dairi Regency, Dairi shallot, product development, Toba Lake

\section{INTRODUCTION}

In North Sumatra, Dairi Regency is located right next to Toba Lake. Besides tourism, Dairi Regency is also rich with its horticultural plants, especially shallots. Dairi Regency has a unique shallot called Dairi shallot and has high production.However, shallots are seasonal plants. When the supply is high, the selling price is low and vice versa so that the price fluctuates [1]. In addition, no processing has been applied to Dairi shallots to become a food product even though it has the potential to become a souvenir of Toba Lake tourism and support it and help to maintain the price stability in the market.

There are a lot of shallot producers in Indonesia. The most known shallots are the one from Brebes and Sumenep. Brebes is a regency in the north-western part of Central Java province and Sumenep is a regency of East Java province. It is expected that different locations and regions might result in the sulphur content and moisture content according to different soil conditions. The sulphur content contributes to the aroma of shallot and moisture content affects the crispiness of fried shallot.

Various processed shallot products are now developing in Indonesia, one of them is fried shallot [2]. Fried shallot has several types, and is commonly produced by various methods. The methods are the vacuum frying method [3] and the normal deep frying method [4], [5]. The types are fried shallot with or without tapioca coating [6], [7], and fried shallot with or without spices [5].Different types of shallot raw material, production methods, and types of fried shallot products will produce different product characteristics. The consumers already have their perception of their preferred fried shallot product characteristic [8], but there is no information about the consumer's preference for fried shallot products made from Dairi shallot.

The packaging is needed to maintain the stability of fried shallot products based on the sensory characteristics and physicochemical [9]. Besides that function, the packaging is also needed to attract consumer attention and support branding strategy. 
Therefore, the analysis of product stability on various packaging is important to choose the most appropriate packaging for the product as a souvenir of Toba Lake tourism. Not just that, the developed product also has to meet the requirements regulated by the Indonesian National Agency of Drug and Food Control (BPOM). Sothe conformity analysis of fried Dairi shallot product to the regulation is important because by confirming the regulation, the product can be sold to the market.

Based on all needs, this research has characterized the Dairi shallot compared to shallot from other places. This research also determined the most preferred fried shallot type made from Dairi shallot. The type chosen has been analysed for its stability on two types of packaging based on sensory evaluation and peroxide number. Some quality parameters were also analysed for the product compliance with the BPOM regulation for fried shallot products. The market acceptance of the product as a souvenir of Toba Lake tourism was also evaluated in this research.

The objectives of this research are to evaluate the sulphur content and moisture content of Dairi shallot, compare to Brebes and Sumenep shallot, to determine the most preferred type for fried shallot made from Dairi shallot based on sensory analysis, to determine the most appropriate packaging for fried shallot made from Dairi shallot, based on the stability assessments, to evaluate the market acceptance of fried shallot products made from Dairi shallot as the souvenir of Toba Lake Tourism, and to assess the safety parameter and nutritional value according to BPOM regulation.

\section{MATERIALS AND METHOD}

The materials used in this study were Dairi shallot (Silahisabungan, Dairi Regency, North Sumatra), palm cooking oil, tapioca flour, and cooking salt for the production of fried shallot. All acquired from local shops. For the analysis, chloroform (EMSURE, Germany), acetic acid (glacial) 100\% (EMSURE, Germany), potassium iodide (BDH, England), starch powder for the analysis, and sodium thiosulfate pentahydrate (MERCK, Germany) were used. The materials used for the test that were done by external lab were Xylose Lysine Deoxycholate (XLD) agar, agar media, phenol, sulphuric acid, hydrochloric acid, sodium carbonate, and petrol ether

The equipment used in this research were stove, slicer, cutter, pan, spatula, oil filter, weighing scale, spinner as oil drainer (NAKULA, Indonesia), timer, cooking thermometer, plastic jar, and composite can for the production of fried shallot. For the analysis, analytical balance, burette, Erlenmeyer flask $250 \mathrm{ml}$, graduated pipette, and spatula were used. The equipment used for the test that were done by external lab were oven, ICP-OES spectrometer, LC MS MS spectrometer, ICP MS spectrometer, microbiological incubator, Bunsen burner, glass spreader, petri dish, inoculating loop, autoclave, gas chromatograph, boiling tube, test tube, water bath, centrifuge, and Kjeltec distillation unit.

\subsection{Sulphur and Moisture Content Analysis}

The research starts by analysing the sulphur content and moisture content of the Dairi shallot as the raw material. The results were compared to Brebes and Sumenep shallot. Sulphur content was analysed by using Inductively Coupled Plasma - Optical Emission Spectrometry (ICP-OES) in accordance with 18-131/MU/SMM-SIG. Moisture content was analysed by using the oven method following the regulation of SNI 01-2891-1992 point 5.1.

\subsection{Determination of The Most Preferred Fried Shallot Type Based on Sensory Evaluation}

Shallot from Dairi regency was sorted, peeled, washed, and sliced using a slice to have the same thickness. After that, the shallots were processed into deep frying with 4 different types of product. Each formulation was weighed 300 grams, fried conventionally at $102^{\circ} \mathrm{C}-104^{\circ} \mathrm{C}$ for 25 to 45 minutes [10], and drained to reduce excess oil by using an oil drain spinner for 5 minutes. Each formulation was repeated two times where each repetition is considered as a group.

$$
\begin{aligned}
& \mathrm{A}=\text { uncoated } \\
& \mathrm{B}=\text { coated with tapioca flour } 1 \%(\mathrm{w} / \mathrm{w})[7] \\
& \mathrm{C}=\text { soaked in } 1.5 \% \text { salt solution } \\
& \mathrm{D}=\text { soaked in } 1.5 \% \text { salt solution and coated with } \\
& \quad \text { tapioca flour } 1 \%(\mathrm{w} / \mathrm{w})
\end{aligned}
$$

Sensory evaluation was conducted through a Hedonic ranking test and a 9-point Hedonic scale test to obtain the most preferred method of fried shallot by consumers. The sensory test was conducted by using 41 panelists. They were asked to score their rank and preference for each fried shallot). Fried shallot product with the highest score was chosen and used for the next step. 


\subsection{Determination of The Most Appropriate Packaging for Fried Shallot Product Based on Stability Assessments}

The most preferred fried shallot type was processed to determine the best packaging material for product stability. The two types of packaging were analysed, plastic jar and composite can. Peroxide number and sensory characteristics were used as the parameter to analyse the stability of the product during storage. Sensory characteristics were evaluated by 24 panelists on day 7 of storage and 6 panellists on days 14 and 21 of storage due to the lockdown period.

\subsection{Evaluation of Market Acceptance as Toba Lake Tourism's Souvenir}

While the stability of the product was observed, the label of packaging was developed by following the regulations of the Indonesian Food and Drug Administration (BPOM). After that, the market acceptance of the developed product as a souvenir from Toba Lake tourism was conducted through a survey towards 133 respondents.

\subsection{Assessment of Safety Parameters and Nutritional Value According to ВРОМ}

At the end, the quality of the developed product was analysed at a certified laboratory based on the BPOM regulation for fried shallot products, both on safety parameters and nutritional value.

\section{RESULTS AND DISCUSSION}

\subsection{Sulphur and Moisture Content Analysis}

Shallot has a similar physical appearance. The size is small like garlic with a purple reddish color and it has a sulphur aroma, not like garlic nor onion. But there are differences in characteristics between shallots that might be influenced by several factors such as seeds, planting location, planting height, soil conditions, and others. The differences can be seen in Figure 1.

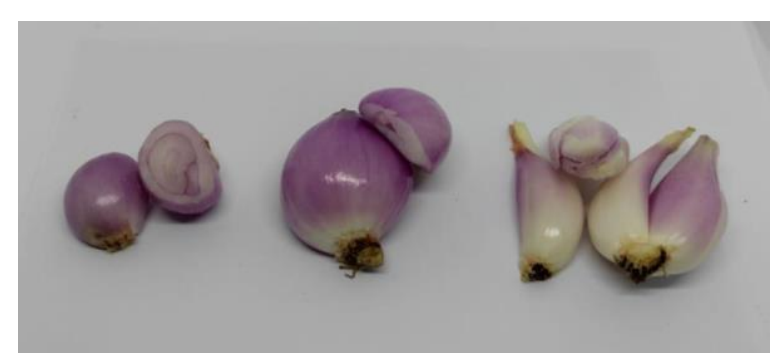

Figure 1 Raw shallot from Dairi, Brebes, and Sumenep (left to right)

The shallot from Dairi, Brebes, and Sumenep come from different regions, North Sumatra, Central Java, and East Java, respectively. They have different physical appearances. Brebes shallots seem to have the most intense reddish-purple color while Sumenep shallots tend to be very pale because they are dominated by white with a slight purplish. Dairi shallots also have a color that is similar to Brebes shallot. In terms of size, Brebes shallots are much larger than Dairi shallot even though both have a round shape. Meanwhile, Sumenep shallot has a long oval shape. They were cut transversely and turned out that they have different appearance structures inside.

Shallot from Dairi, Brebes, and Sumenep was expected to have different sulphur content as they came from different locations and regions with also different soil conditions. And it turned out that each shallot has different moisture and sulphur content as can be seen from Table 1 .

Table 1 Moisture content and sulphur content of shallot

\begin{tabular}{|c|c|c|c|}
\hline & Dairi & Brebes & Sumenep \\
\hline $\begin{array}{c}\text { Moisture } \\
\text { content (\%) }\end{array}$ & $\begin{array}{c}81.64 \pm \\
0.34\end{array}$ & $\begin{array}{c}82.21 \pm \\
0.36\end{array}$ & $\begin{array}{c}79.78 \pm \\
0.35\end{array}$ \\
\hline $\begin{array}{c}\text { Sulphur } \\
\text { content } \\
(\mathrm{mg} / \mathrm{kg})\end{array}$ & $\begin{array}{c}612.22 \pm \\
14.17\end{array}$ & $\begin{array}{c}641.00 \pm \\
0.49\end{array}$ & $\begin{array}{c}679.25 \pm \\
1.05\end{array}$ \\
\hline
\end{tabular}

Sumenep shallots have the most sulphur volatile compound, followed by Brebes shallots then Dairi shallots, which contain $679.25 \mathrm{mg} / \mathrm{kg}, 641.00 \mathrm{mg} / \mathrm{kg}$, and $612.22 \mathrm{mg} / \mathrm{kg}$ respectively. The analysis of sulphur content aims to see the differences in the characteristics of the aroma of each shallot. Based on the reference[11], [12], the chemical that contributes to the aroma of shallot contains sulphur so that if the total sulphur can be analysed, it means the differences in the characteristics of aroma are also can be known. 
And Sumenep shallot, as it has the most sulphur compound, so is expected to have a stronger aroma. And for moisture content, Brebes shallots contain the most $(82.21 \%)$, followed by Dairi shallots $(81.64 \%)$ then Sumenep shallots $(79.78 \%)$. Moisture content was analysed to know whether the differences in moisture content of each shallot have an impact on the crispiness of fried shallot or not.

\subsection{Determination of The Most Preferred Fried Shallot Type Based on Sensory Evaluation}

Four different methods of frying the shallot were done as can be seen in Figure 2 and using sensory evaluation, the most preferred type of fried shallot was chosen. A ranking test was done to assess the characteristics of fried shallot such as colour, aroma, flavour, and crispiness. Panelists were asked to rank from one (1) as the most preferred to four (4) as the least preferred to each parameter of each fried shallot type and the results are as shown in Table 2. And to determine the most preferred fried shallot product based on sensory evaluation, a Hedonic scale test was used. About 42 panelists were asked to scale their preference towards each fried shallot type from one (1) as dislike extremely to nine (9) as like extremely. The results obtained were analysed by using Friedman's test. If there is a significant difference, further analysis was required and conducted by using Wilcoxon's test. Both used the confidence interval of $95 \%$.
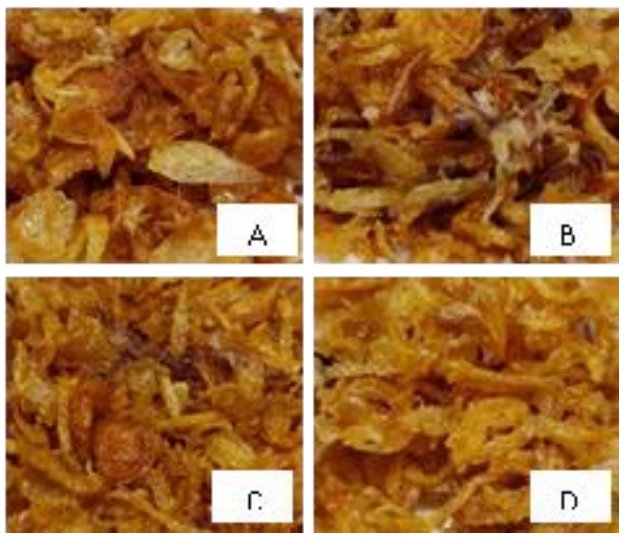

Figure 2 Fried shallot made from Dairi shallot ( $\mathrm{A}=$ uncoated, $\mathrm{B}=$ coated with tapioca, $\mathrm{C}=$ soaked in salt solution, $\mathrm{D}=$ soaked in salt solution and coated with tapioca)
Table 2 Result of ranking test towards each fried shallot attribute. Data are means and standard deviation. Data on the same column with different letters are significantly different $(n=42$, Wilcoxon's test, $\mathrm{P}<0.05$ )

\begin{tabular}{|c|c|c|c|c|}
\hline & Colour & Aroma & Flavour & Crispiness \\
\hline \multirow{2}{*}{ A } & $2.68 \pm$ & $1.85 \pm$ & $2.20 \pm$ & $2.83 \pm$ \\
& $0.95^{\mathrm{b}}$ & $1.05^{\mathrm{a}}$ & $0.99^{\mathrm{a}}$ & $1.12^{\mathrm{b}}$ \\
\hline \multirow{2}{*}{$\mathrm{B}$} & $3.29 \pm$ & $2.44 \pm$ & $3.37 \pm$ & $3.54 \pm$ \\
& $0.83^{\mathrm{c}}$ & $0.86^{\mathrm{b}}$ & $0.82^{\mathrm{c}}$ & $0.67^{\mathrm{c}}$ \\
\hline \multirow{2}{*}{$\mathrm{C}$} & $1.88 \pm$ & $2.59 \pm$ & $1.85 \pm$ & $1.71 \pm$ \\
& $0.99^{\mathrm{a}}$ & $0.96^{\mathrm{b}}$ & $0.93^{\mathrm{a}}$ & $0.77^{\mathrm{a}}$ \\
\hline \multirow{2}{*}{$\mathrm{D}$} & $1.93 \pm$ & $3.07 \pm$ & $2.46 \pm$ & $1.93 \pm$ \\
& $0.81^{\mathrm{a}}$ & $1.20^{\mathrm{c}}$ & $1.08^{\mathrm{ab}}$ & $0.75^{\mathrm{a}}$ \\
\hline
\end{tabular}

$\mathrm{A}=$ uncoated, $\mathrm{B}=$ coated with tapioca flour $1 \%, \mathrm{C}=$ soaked in $1.5 \%$ salt solution, $\mathrm{D}=$ soaked in $1.5 \%$ salt solution and coated with tapioca flour $1 \%$

According to Table 2, it is seen that the fried shallot that was soaked in salt solution and the one that was soaked in salt solution and coated with tapioca flour (D) were the most preferred product by panelists. While fried shallot coated with tapioca flour had the highest value in terms of mean rank which means it was the least top rank among the other samples. Because the chloride ions in the salt prevent the polyphenol oxidase enzymes from working properly and reduce the water content, the salt solution is efficient in slowing down the browning process. When oxygen comes into contact with foods that include fat or pigments, oxidation occurs which causes unpleasant odour and flavours or colour changes. For aroma attributes, the uncoated fried shallot was the most preferred fried shallot by panelists as it had the lowest mean rank. While the fried shallot that was soaked in salt solution and coated with tapioca flour (D) was the least preferred which has the highest value of mean rank $(3.07 \pm 1.20)$. And there was no difference between fried shallot coated with tapioca flour and the fried shallot that was soaked in a salt solution. Based on prior research about consumer perceptions towards fried shallot, it was proved that consumers are preferred to fried shallot with a fragrant sulphuric aroma in high intensity.In terms of flavour attribute, uncoated fried shallot and fried shallot that was soaked in salt solution had the same ranking score. While fried shallot coated with tapioca flour was the least preferred by consumers. Adding salt to many foods boosts love for that food up to a degree, after which adding more salt diminishes its pleasantness (palatability). There are significant individual variances in where the optimal point (dubbed the "bliss point") for any given dish is located, which is most 
likely related to variances in salt experience with that item and other food [13]. In terms of crispiness, the fried shallot that was soaked in salt solution and soaked in salt solution and coated with tapioca flour (D) had the same ranking score. However, fried shallot coated with tapioca flour was the least preferred by panelists among other samples including the uncoating. [14] stated that crispness associates to amylose content in a positive way while oil absorption associates to with amylose content in a negative way. Tapioca starch contains approximately $17 \%$ [15] of amylose whilst amylose is the one that is less soluble in water. The degree of polysaccharidepolysaccharide, polysaccharide-water, polysaccharide-oil, and polysaccharide-protein interaction is most likely a factor in the hardness of fried batters. Because of the branches' amylopectin structure's capacity to hold and interact strongly with water, the batter was mushy. Coatings have an impact on starch gelatinization which can result in a crust forming on the food's surface, and the lower the moisture content, the crunchier the product will be [16].

Table 3 were the result for overall acceptance by panellists for each type of fried shallot.

Table 3 Result of hedonic scale test towards overall acceptance. Data are means and standard deviation. Data on the same column with different letters are significantly different ( $\mathrm{n}=42$, Wilcoxon's test, $\mathrm{P}<0.05$ )

\begin{tabular}{|l|c|}
\hline & $\begin{array}{c}\text { Overall } \\
\text { Acceptance }\end{array}$ \\
\hline Uncoated & $6.73 \pm 1.59^{\mathrm{a}}$ \\
\hline Coated with tapioca flour 1\% & $4.61 \pm 1.65^{\mathrm{b}}$ \\
\hline Soaked in 1.5\% salt solution & $7.17 \pm 1.32^{\mathrm{a}}$ \\
\hline $\begin{array}{l}\text { Soaked in 1.5\% salt solution and } \\
\text { coated with tapioca flour 1\% }\end{array}$ & $7.27 \pm 1.08^{\mathrm{a}}$ \\
\hline \multicolumn{2}{|l}{ Score 1 means dislike extremely and score 9 means like extremely }
\end{tabular}

According to Table 3, it showed that fried shallot with the addition of tapioca flour was the least preferred by panellists while the other samples were in the same position for overall acceptance. They had no different at all from each other. The fried shallot that was soaked in salt solution and the one that was soaked in salt solution and coated with tapioca flour (D) had the same overall acceptance score. But in the ranking test of each attribute (Table 2), $\mathrm{C}$ had the most top rank for three (3) attributes. So as the fried shallot that soaked in salt solution was overall accepted by panellists and the most preferred in terms of colour, flavour, and aroma, therefore it was determined that the most preferred fried shallot type is fried shallot that soaked in $1.5 \%$ salt solution.

\subsection{Determination of The Most Appropriate Packaging for Fried Shallot Product Based on Stability Assessments}

\subsubsection{Peroxide Number}

After the most preferred fried shallot typed selected, then the appropriate packaging was analysed. During storage, fats and oils can undergo a variety of processes, including oxidation, hydrolysis, and polymerization. It is quite difficult to figure out how separate reactions combine to generate dangerous chemicals. Almost all of these processes, on the other hand, involve oxidation and are mediated by lipid hydroperoxides. Figure 4.4 shows the peroxide number of both packaging from day 0 (zero) to day 21 (twenty-one). The y-axis is the peroxide number in milliequivalents per kilogram (meq $/ \mathrm{kg}$ ) and the $\mathrm{x}$-axis is the time period in day. Sensory characteristics were evaluated by 24 panellists on day 7 of storage and 6 panellists on days 14 and 21 of storage due to the lockdown period.

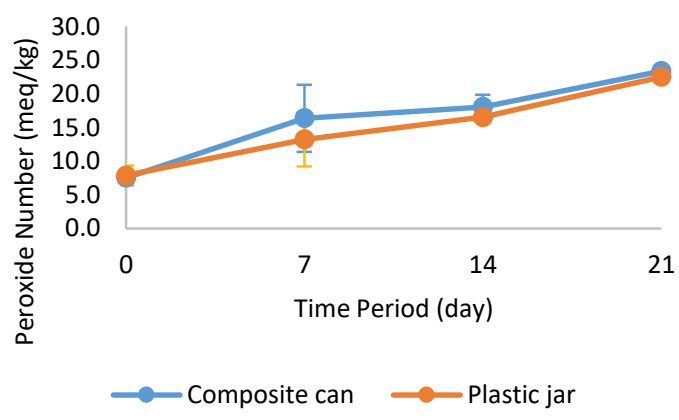

Figure 3 Peroxide number of fried shallots stored in different types of packaging for 21 days. Data are means and standard deviations.

From Figure 3, it can be seen that both packaging, composite can and plastic jar, had a similar pattern of effectiveness after being stored for 21 days, judging from the same rate of peroxide number which was seen based on the slope value of linear regression. The linear equation of composite can was $y=0.7038 x+$ 8.9515 with $\mathrm{R}^{2}$ of 0.9314 which indicates that the regression model accounts for $93.14 \%$ of the variation in the dependent variable. The p-value was $(0.035)$ is less than the significance level (0.05) which indicates that the result was statistically significant during storage. The linear equation of the plastic jar was $\mathrm{y}=$ 
$0.6747 x+7.955$ with $R^{2}$ of 0.9891 which indicates that the regression model accounts for $98.91 \%$ of the variation in the dependent variable. The $\mathrm{p}$-value was $(0.005)$ is less than the significance level (0.05) which indicates that the result was statistically significant during storage. Both packaging had no difference in the peroxide number pattern, so that it can be concluded that both was appropriate to pack the fried shallot. The concentration of unsaturated lipids can be determined by knowing the peroxide number of the sample. It is required because unsaturated lipids are prone to lipid oxidation. When lipids oxidize, they produce unpleasant tastes and aromas, vitamins deteriorate, and hazardous chemicals may be released. The term "rancid" refers to the consequence of lipid oxidation. The presence of double bonds in unsaturated lipids makes them easily oxidized. Lipid peroxidation is caused by the action of free radicals on the double bonds of unsaturated lipids.

\subsubsection{Sensory Evaluation}

In addition to the peroxide number, changes in sensory characteristics were also found during 21 days of storage. To obtain the changes of sensory characteristics, a Hedonic scale test was conducted at day $0(\mathrm{D}+0)$, a week storage (D+7), two weeks storage $(\mathrm{D}+14)$, and three weeks storage $(\mathrm{D}+21)$. Panelists were asked to assess their preference towards each parameter and overall acceptance of fried shallot. On day 0 , the value of fried shallot in the composite can and the plastic jar were the same for each parameter and overall acceptance. Graph 4.6 shows the sensory evaluation of fried shallot stored in the composite can and Graph 4.7 shows the sensory evaluation of fried shallot stored in the plastic jar. The y-axis is the Hedonic score and the $\mathrm{x}$-axis is the time period in day.

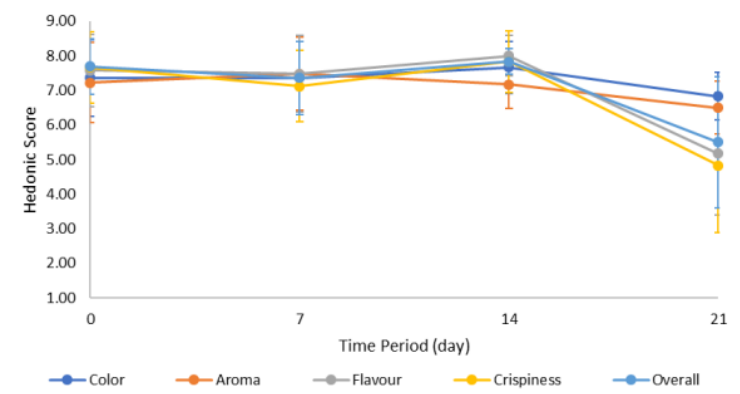

Figure 4 Sensory evaluation of fried shallot in composite can

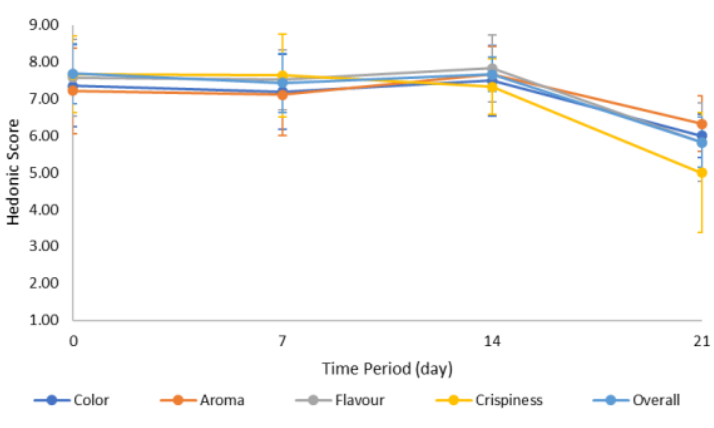

Figure 5 Sensory evaluation of fried shallot in plastic jar

Both graphs showed that the composite can and plastic jar had the same pattern of sensory evaluation after being stored for 21 days. They had a peak at day 14 which means the shelf life of the product is up to 14 days. On a 9-point scale, a mean Hedonic score of 7 or greater is usually indicative of extremely acceptable sensory quality; thus, a product reaching this score might be securely utilized as a good representation of 'target' quality [17].

On day 21, the crispiness attribute had the lowest Hedonic score. This might be due to the effect of headspace inside the packaging which is important for maintaining quality. Headspace might contain oxygen that is highly reactive with other molecules and also oxidizes fats and oils. Crisps, like food products that can be stored for up to six months, require the lowest possible moisture levels, and the aluminium foil pack preserves moisture levels below the maximum limit in all storage situations. According to the research of [18], potato crisps placed in opaque aluminium packs absorbed less moisture than those in transparent polyethylene bags, which is important because moisture can cause the product to produce unacceptable sensory characteristics. In comparison to polyethylene bags, aluminium foil packs have been demonstrated to keep crisps acceptable for longer periods.

\subsubsection{The Most Appropriate Packaging}

From the peroxide number parameters for fried shallot, it can be seen that the composite can and the plastic jar had similar patterns after being stored for 21 days. And from the sensory characteristics, both packaging also had the same pattern of sensory evaluation. Therefore, they were appropriate to pack the fried shallot. But plastic jar was the chosen 
packaging due to its cheaper price and transparent material which were more preferred by panelists.

\subsection{Evaluation of Market Acceptance as Toba Lake Tourism's Souvenir}

The product acceptance in the market as a souvenir of Toba Lake tourism was carried out through a survey using a 9-scale Hedonic test. Number one (1) refers to extreme dislike to buy the fried shallot product and number nine (9) refers to extreme liking to buy. The fried shallot product was as shown in Figure 6.

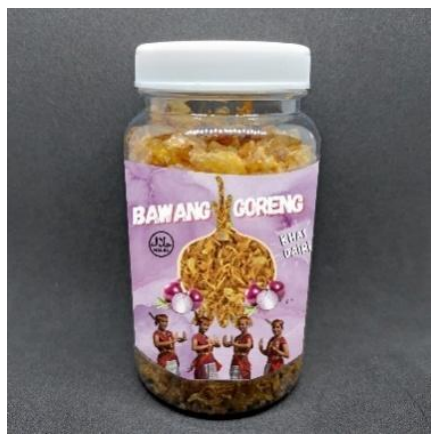

Figure 6 Fried shallot products

There were 133 respondents involved in this survey who were considered as local tourists from Jakarta and Tangerang. They were asked to give a score of how much they would buy as a souvenir from Toba Lake for Rp 30,000 or equivalent to 2 US\$ or 1.8 Euro with a net weight of 100 grams. And the results are as shown in Figure 4.9. 90\% of respondents like to buy the product as a souvenir. They assess the product as a souvenir and the transparent packaging so that they can see the fried shallot product for real, and the prices are affordable and even relatively cheap for them. Abong et al. (2011) [18] stated that if market acceptability of products has to be maintained, proper packaging and storage of crisps in acceptable circumstances is an absolute must.

\subsection{Assessment of Safety Parameters and Nutritional Value According to BPOM}

The developed product was assessed for its safety parameter and nutritional value according to BPOM regulation. The safety parameters for product quality are written on BPOM regulation number 8 year 2018 about the maximum limit of chemical contamination in processed food, number 5 year 2018 about the maximum limit of heavy metals contamination in processed food, and number 13 year 2019 about the maximum limit of microbes contamination in processed food. The requirements from BPOM and the quality of the Dairi fried shallot are as shown in Table 4.

Table 4 Safety parameters based on BPOM regulation

\begin{tabular}{|l|c|c|}
\hline Parameter & $\begin{array}{l}\text { BPOM } \\
\text { standard }\end{array}$ & $\begin{array}{l}\text { Dairi fried } \\
\text { shallot }\end{array}$ \\
\hline Aflatoxin B1 (mcg/kg) & 15 & Not detected \\
\hline $\begin{array}{l}\text { Total Aflatoxin } \\
(\mathrm{mcg} / \mathrm{kg})\end{array}$ & 20 & Not detected \\
\hline $\mathrm{Hg}(\mathrm{mg} / \mathrm{kg})$ & 0.05 & Not detected \\
\hline $\mathrm{Cd}(\mathrm{mg} / \mathrm{kg})$ & 0.50 & Not detected \\
\hline $\mathrm{As}(\mathrm{mg} / \mathrm{kg})$ & 0.15 & Not detected \\
\hline $\mathrm{Sn}(\mathrm{mg} / \mathrm{kg})$ & 40 & Not detected \\
\hline $\mathrm{Pb}(\mathrm{mg} / \mathrm{kg}) \quad 1$ & 0.12 \\
\hline Salmonella sp. (/25 g) & Negative & Negative \\
\hline $\begin{array}{l}\text { Bacillus cereus } \\
\text { (colony/g) }\end{array}$ & $10^{4}$ & $<10$ \\
\hline $\begin{array}{l}\text { Clostridium } \\
\text { perfringens (colony } / \mathrm{g})\end{array}$ & $10^{3}$ & $<10$ \\
\hline
\end{tabular}

According to BPOM regulation, Aflatoxin B1 and Total Aflatoxin should not contain more than 15 and 20 micrograms per kilogram respectively. Aflatoxin is produced by the fungus Aspergillus flavus which contaminates plants and herbs as it grows in a tropical climate and humid area and is hydrophobic or does not like water. In addition, Aflatoxin is resistant to high temperatures. There are six types of Aflatoxin but the most toxic for humans is Aflatoxin B1 which can stimulate cancer. For heavy metals, no more than 0.05 milligram per kilogram of mercury $(\mathrm{Hg}), \quad 0.50$ milligram per kilogram of cadmium (Cd), 0.15 milligram per kilogram of arsenic (As), 40 milligrams per kilogram of tin $(\mathrm{Sn})$, and 1 milligram per kilogram of lead $(\mathrm{Pb})$. Heavy metal contamination comes from nature or pesticides used for shallots and some of them are bound to elements such as oxygen, chlorine, and sulphur [19]-[21]. These heavy metals are toxic to humans if consumed exceeds the maximum limit that has been set causing kidney damage, stunted growth, bone fragility, cancer, and other. For microbes, the presence of Salmonella sp. should not be detected or detected as "negative", no more than $10^{4}$ colonies per gram of Bacillus cereus, and $10^{3}$ colonies per gram of Clostridium perfringens. Salmonella is a pathogenic bacterium that causes infections in the human digestive system. Bacillus cereus causes food poisoning resulting in diarrhea or stomach cramps. Clostridium perfringens is a pathogenic bacterium that is toxic to humans and causes wound infections. Nevertheless, all the safety parameters were met by Dairi fried shallot. 
Table 5 is the nutritional value of Dairi shallot which follows the BPOM regulation number 22 year 2019 about the nutrition value on food labels. It should contain the information of serving size, amount of servings per pack, amount per serving, type and amount of nutrients and non-nutrient, daily value percentage, and footnote about the daily value. The nutrients that must be included are total energy, total fat, saturated fat, protein, total carbohydrate, sugar, and sodium (salt). And the nutritional value of Dairi fried shallot met the regulation.

Table 5 Safety parameters based on BPOM regulation

\begin{tabular}{|c|c|c|}
\hline \multicolumn{3}{|c|}{ Nutritional Value } \\
\hline \multicolumn{2}{|l|}{ Serving size } & $10 \mathrm{~g}$ \\
\hline \multicolumn{2}{|c|}{ AMOUNT PER SERVING } & $\begin{array}{r}\text { (10 servings } \\
\text { per pack) }\end{array}$ \\
\hline \multicolumn{2}{|l|}{ Total energy } & 60 kcal \\
\hline \multicolumn{2}{|l|}{ Energy from fat } & $40 \mathrm{kcal}$ \\
\hline \multicolumn{2}{|c|}{ Energy from saturated fat } & $15 \mathrm{kcal}$ \\
\hline \multirow{8}{*}{$\begin{array}{l}\text { Total fat } \\
\text { Saturated fat } \\
\text { Protein } \\
\text { Total carbohydrate } \\
\text { Sugar } \\
\text { Sodium }\end{array}$} & \multicolumn{2}{|c|}{ \% Daily Value* } \\
\hline & $4.5 \mathrm{~g}$ & $7 \%$ \\
\hline & $2 \mathrm{~g}$ & $9 \%$ \\
\hline & $\mathbf{0} \mathbf{g}$ & $\mathbf{0 \%}$ \\
\hline & $5 \mathrm{~g}$ & $1 \%$ \\
\hline & $\mathbf{0} \mathbf{g}$ & \\
\hline & 70 & $5 \%$ \\
\hline & mg & \\
\hline $\begin{array}{l}\text { *The \% Daily Value } \\
2,150 \text { kcal. Your e } \\
\text { higher or lower. }\end{array}$ & $\begin{array}{l}\text { Dased } \\
\text { requir }\end{array}$ & $\begin{array}{l}\text { energy needs } \\
\text { nts may be }\end{array}$ \\
\hline
\end{tabular}

\section{CONCLUSION}

Each shallot has different sulphur content and moisture content. The most preferred type for fried shallot made from Dairi shallot based on sensory evaluation was the fried shallot that was soaked in a $1.5 \%$ salt solution. And based on the stability test, composite can and plastic jar were appropriate to pack the fried shallot. However, the plastic jar was chosen as the most appropriate packaging as it is cheaper and panelists prefer the packaging where the contents of the product can be seen. After that, the fried shallot product was evaluated for market acceptance as the souvenir of Toba Lake Tourism and the results showed almost all respondents were interested in buying the fried shallot product. The safety parameters and nutritional value of Dairi fried shallot were met by the BPOM regulations.

The significance of the study from this research is developing the product from Dairi shallot to stabilize the market price of shallot, increase the shelf life, and add more economic value to the shallot commodity in Dairy Regency. The product is expected to support the tourism in Dairi Regency and increase the welfare of people in the Dairi Regency directly.Further research is required to analyse moisture content as a parameter that may correlate with the stability of the texture. In addition, an observation towards essential oil content in Dairi shallot, Brebes shallot, and Sumenep shallot are required to find out the effect on the sensory characteristics of fried shallot. Furthermore, the use of standing pouch aluminium foil filled with nitrogen gas needs to be observed for its impact on the oxidation process.

\section{REFERENCES}

[1] Darmawidah, W. Dewayani, Cicu, and E. Y. Purwani, "Teknologi Pengolahan Bawang Merah," Pros. Semin. Nas. Teknol. Inov. Pascapanen untuk Pengemb. Ind. Berbas. Pertan., pp. 628-636, 2010.

[2] N. Arfinanti, "Upaya Peningkatan Nilai Tambah Produk Bawang Merah (Tindak Lanjut KKN di Desa Selopamioro, Imogiri, Bantul)," J. Teknol. Ind. Pertan., vol. 19, pp. 41-52, 2019.

[3] N. Therdthai, Phaisan Wuttijumnong, A. Jangchud, and C. Kusucharid, "Optimization of Vacuum Frying Condition for Shallot," Kasetsart J. Nat. Sci., vol. 041, no. 5, pp. 338342, 2007.

[4] Trismawati, A. Basit, and R. Nuriyanti, "Camilan Bawang Khas Probolinggo dalam Menghadapi Persaingan Pasar Nasional," $J$. Pengabdi. Kpd. Masy. IKIP Siliwangi, vol. 01, no. c, pp. 81-88, 2018.

[5] Iriani, "Pengendalian Kualitas Bawang Merah Goreng Industri Rumah Tangga,” J. Tek. Kim., vol. 1, no. 2, 2007.

[6] N. Anisa, Rostianti, and S. Kadir, "Mutu Bawang Goreng dari Bawang Merah Lembah Palu," vol. 1, no. April, pp. 37-43, 2013, [Online]. Available: https://lens.org/152-912049-680-347.

[7] N. Alam, Rostiati, and Muhardi, "Sifat FisikKimia dan Organoleptik Bawang Goreng Palu Pada Berbagai frekuensi Pemakaian Minyak Goreng," Agritech, vol. 34, no. 4, pp. 390398, 2014.

[8] O. Yofananda, C. H. Wijaya, H. N. Lioe, and Sobir, "Fried Shallot Quality: Perception and Differentiation," Curr. Res. Nutr. Food Sci., vol. 8, no. 1, pp. 97-106, 2020.

[9] C. C. Chyau, Y. C. Lin, and J. L. Mau, "Storage Stability of Deep-Fried Shallot Flavoring," J. Agric. Food Chem., vol. 45, no. 8, pp. 3211-3215, 1997. 
[10] Suratija and S. Luwihana, "Karakteristik Bawang Merah (Allium cepa var. Brebes) Goreng dari Berbagai Metode Vakum dan Konvesional," Semin. Nas., pp. 236-239, 2012.

[11] R. J. McGorrin, "The Significance of Volatile Sulfur Compounds in Food Flavors," ACS Symp. Ser., vol. 1068, pp. 3-31, 2011.

[12] L. Charoenshai, C. Luprasong, and D. Meksuriyen, "Characterization of Some Organosulfur Compounds in Shallot Bulbs," Thai J. Pharm. Sci., vol. 42, no. supplement, pp. 93-97, 2018, [Online]. Available: http://www.tjps.pharm.chula.ac.th/proceeding s/backend/proceeding_file/24_PN_FP_Sukan ya Settharaksa (102-106).pdf.

[13] J. E. Henney, C. L. Taylor, and C. S. Boon, Taste and Flavor Roles of Sodium in Foods: A Unique Challenge to Reducing Sodium Intake. 2010.

[14] S. Mohamed, N. A. Hamid, and M. A. Hamid, "Food Components Affecting The Oil Absorption and Crispness of Fried Batter," J. Sci. Food Agric., vol. 78, no. 1, pp. 39-45, 1998.

[15] M. N. Riaz, Snack Foods: Processing, 2nd ed., vol. 3-4. Elsevier Ltd., 2015.

[16] R. Wibowo, C., Eminawati, Haryanti, P., and Wicaksono, "Effect of Starch-Based Edible Coating Application on Potato Chips Characteristic," Food Res., vol. 4, no. December, pp. 1905-1911, 2020.

[17] M. Everitt, Consumer-Targeted Sensory Quality, First Edit. Elsevier Inc., 2009.

[18] G. O. Abong, M. W. Okoth, J. K. Imungi, and J. N. Kabira, "Effect of Packaging and Storage Temperature on the Shelf Life of Crisps from four Kenyan Potato Cultivars," Am. J. Food Technol., pp. 882-892, 2011.

[19] Badan Standardisasi Nasional, "Batas Maksimum Cemaran Logam Berat dalam Pangan," Batas Maksimum Cemaran Logam Berat dalam Pangan, p. 17, 2009, [Online]. Available: https://sertifikasibbia.com/upload/logam_ber at.pdf.

[20] P. Hajeb, J. J. Sloth, S. Shakibazadeh, N. A. Mahyudin, and L. Afsah-Hejri, "Toxic Elements in Food: Occurrence, Binding, and Reduction Approaches," Compr. Rev. Food Sci. Food Saf., vol. 13, no. 4, pp. 457-472, 2014.

[21] Rasman and Hasmayani, "Faktor-Faktor yang Mempengaruhi Kandungan Timbal (Pb) Pada Bawang Merah (Allium cepa) di Desa Pekalobean Kabupaten Enrekang," Media Komun. Sivitas Akad. dan Masy., vol. 18, no.
I, pp. 47-52, 2018, [Online]. Available: http://www.tjyybjb.ac.cn/CN/article/downloa dArticleFile.do?attachType=PDF\&id=9987. 